\title{
Undergraduates Student Perceptions' of Social Networking Sites to Improve English Writing Skills in Malaysia
}

\author{
Nurul Afifah Binti Azlan and Melor Md Yunus* \\ Universiti Kebangsaan Malaysia \\ Bangi Selangor, Malaysia
}

\begin{abstract}
This article presents the perception of the use of SNSs in improving English writing skills among undergraduates' students. English writing skills are among the most critical skills that every level of the student requires to empower. However, it was discoverable that university students particularly still facing trouble in English writing. Therefore, this study is to investigate the students' perception in the use of SNSs in improving English writing skills and also to identify the students' SNSs preferences to practice English writing. As to garner the data, survey questionnaires were distributed comprises of open-ended and close-ended sections that were distributed among 118 undergraduate students. The respondents were ESL learners from different faculty from MARA University of Technology Malaysia (UiTM) and University Technology Petronas (UTP) in Malaysia. The quantitative and qualitative research approach is used to interpret the collected data. Descriptive statistics are used to showcase the data gathered from the findings. The findings from the survey conducted displayed that the respondents respond affirmatively on the usage of SNSs in improving English writing skills. Thus, the inculcation of SNSs in teaching and learning activities could allow educators and learners to practice English writing. Further studies on the effectiveness of the application of SNSs should be conducted among the undergraduates' students as it is also in line with

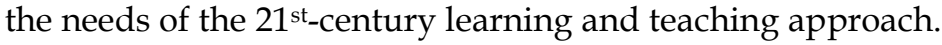

Keywords: SNSs; English Writing Skills; 21 ${ }^{\text {st }}$ Century Learning; Vygotsky's Social Cultural Theory; Perception

\section{Introduction}

Fundamentally, four main components of English need to be learned by the ESL, which are reading, writing, speaking, and listening. According to Yang Silin \& Andrea Chan (2015), in today's setting, the ability to produce an excellent piece of writing allows a person to have the opportunity to share their ideas and opinions

\footnotetext{
* Corresponding author: Melor Md Yunus, Email: melor@ukm.my
} 
globally. In Malaysia, English writing is examined throughout the exam from every level of education. As to continue to tertiary level, students need to sit for (Malaysian University Examination Test (MUET), and writing is part of the test components. Furthermore, students are also required to take the English course at university and college. However, writing could be one of the complicated tasks to be done by the students, particularly when they need to have an extensive vocabulary and to combine the ideas to produce a piece of writing ( Yunus, Hashim, Edwin, Ho, 2019). In relevant to that, by referring to the specific comments by the examination board from the Malaysian Examination Council (MEC), in 2018 MUET's report, the students were having trouble in presenting the correct overview and conclusion, use simple vocabulary, repetitive sentence structures and also misunderstood the task. The other issues identified from the report, the students, or candidates failed to link to the information in the visuals given, correct sentence structure, and logical connections. Therefore, the problem is continuous every year, not only for the candidates but possibly for the other students.

This research aims to identify the use of SNSs (SNS) to develop English writing skills by examining the perception of undergraduates and their SNSs' preferences for English writing practice. The significance of the study is to find another platform to teach and learn the skills of English writing. Moreover, this research is also intended to cultivate a contemporary approach of assisting the learners to enhance English writing. Penprase (2018) also claimed that, in the 4.0th Industrial Revolution, there is a potential for a revolutionary form of the curriculum to be created with more degrees of choices and new programs in general education designed to produce a wide range of studies through the selection of elective courses. In addition, with the growth of online education and the intensifying use of AI, new strategies are required to provide a theoretical foundation for digital pedagogy (Penprase, 2018). Therefore, this study hopes to assist the learners to improve their English writing skills.

Concerning the study, the use of SNS has become the norm in today's' life, including in the implementation of SNS as part of the curriculum. Few studies were done to evaluate the effectiveness and potential of SNS for teaching at higher learning institutions. However, there is still the need to explore the undergraduates' perception and their SNS' preferences in improving English writing skills.

According to (Altakhaineh \& Al-Jallad, 2018), they reported that the implementation of Social Media could facilitate educators to coordinate the textbooks curriculum and training with the new technology. Moreover, as quoted in (Altakhaineh \& Al-Jallad, 2018), it was found that Facebook has become the substitute approach endorsed to deliver English writing lesson and prove to influence their English writing (Yunus et al., 2013.). In addition, after learning the lessons in their blog posts, students strengthened their English writing (Alsubaie \& Madini, 2018).

Although it was found that a significant number of participants showed a positive attitude and willingness to use SNS in writing classes by considering the attitude 
and perceptions of SNS in improving their skills as a writer Sakkir, Rahman, \& Salija, 2016). Likewise, (Mohammad, Ghazali, \& Hashim, 2018) discovered that the participants showed strong use expectations of the usage of Google+ towards ESL writing.

Due to that, as to achieve the primary purpose of this research, survey questionnaires consisting open-ended and close-ended have been distributed among undergraduates' students from University Technology Mara, Shah Alam, and University Technology Petronas, Perak, Malaysia.

\section{Literature review}

To obtain further clarification on this study, the review will explore on the Social Networking Sites(SNS) and English writing skills, perception on SNSs in improving English writing skills in concurrently with learning theories applied for this study which are social constructivist learning theory from Vygotsky's and Technology Acceptance Model (TAM).

\subsection{Social Networking Sites}

Gupta \& Bashir (2018) notes that the use of SNSs means online space for students to interact, chat, or maintain ties for education, entertainment, socialization, and other purposes. In addition, SNSs' role as a communication medium is rapidly growing, mainly as mobile applications thrive (Gupta \& Bashir, 2018). Apart from that, most SNSs enable users in their networks to share their opinions, preferences, activities, and events (Yunus, Salehi, \& Chenzi, 2012). They also added that the SNSs are social network-based and give users various ways of communicating via the internet, e-mail, or immediate messaging (Yunus, Salehi, and Chenzi, 2012).

It was stated that Facebook and Twitter had been the most popular preferences among the users (Yunus, Salehi \& Chenzi, 2012). However, until recently, it has still been actively using by everyone globally. Moreover, Facebook and Twitter are not only the most preferred by the users since the emerging of the different channels such as Blogspot, Instagram, WhatsApp, Telegram, Google+, Tumblr, WeChat, YouTube, LinkedIn, and more. According to J.Clement (2020), from the survey conducted globally, it has been identified that Facebook was the highest preferred, which is 2,449 million, followed by YouTube(2000 million), Whatsapp(1600million), WeChat(1151 million), Instagram (1000million), and more. There is no doubt as this SNSs allow the users to share their information either in written form, videos, and also photos. The users also can easily download the application and access it anytime. The friendly and interactive interference from the website and applications has attracted the users to use it for various reasons in their daily activities.

Meanwhile, recent studies in Malaysia in 2018 show that Facebook has the highest users, with $97.3 \%$ preceded by Instagram (57\%), YouTube (48.4\%), Google+ $(31.3 \%)$, Twitter $(23.8 \%)$ and others. As for messaging applications, WhatsApps is the largest (98.1\%) accompanied by Facebook Messenger (55.6\%), WeChat $(36.8 \%)$, Telegram $(25 \%)$, and more.

Therefore, most studies included these SNSs, including these websites and 
communications applications, to investigate the potential of its function in integrating into the education curriculum and system. Meanwhile, in this study, the researcher includes other websites such as Tumblr and Blogspot as the websites provide more functions for writing activities. The researcher also includes popular SNSs to discover the respondents' preferences. By looking at global and nationally performed statistics and polls, this can be used as part of the analysis.

\subsection{SNSs and English writing skills}

Few studies have been carried out on SNSs and English writing skills. The studies are carried out because of its functionality that enables the users to engage and create active communication. According to (Belal, 2014), the students and the teachers were able to create collective discussions that allow them to switch their thoughts, share information on the course, assignments requisition and evaluation, and helps students develop their performance in writing and speaking. In other respects, (Alnatsheh, 2018) said, web 2.5 is a live term that describes innovations in global web technology and web design that encourage creativity, knowledge exchange, collaboration and accessibility, the latest advancement in knowledge and communication. Consequently, using SNSs in education may benefit the consumer significantly.

Furthermore, according to (Abd, Ali, Ahmed, \& Arabia, 2016), the use of Facebook has been shown to aid the learners in developing their English writing skills by enhancing their use of grammar during practice. Meanwhile, (Altakhaineh \& AlJallad, 2018), their results revealed that participants strengthened their knowledge about writing mechanics in English by using Twitter more than by using Facebook or vice versa.

One of the studies revealed that the pupils' grades are increasing after the implementation of high-five fingers and snack-bars, which is SNSs is part of the learning and teaching platform (Chandran, Plaindaren, Pavadai, \& Yunus, 2019).

Moreover, according to Özdemir \& Aydın( 2015), found that blogging users had better-written skills in their studies on the outcomes of blogging on writing achievements. In the meantime, the blog was used as a resource for encouraging the development of the English writing skills of ESL learners and inspiring English writing learners (Yunus et al., 2014).

Another popular SNSs that has the potential to assist in English writing development is YouTube. The main findings have shown a substantial increase in the number of correct questions posed in sub-test results, which suggests an awareness of social speech (Raj, Ann, Subramaniam, \& Yunus, 2019). Thus, any kind of SNSs has its potential and has contributed to the development of English writing.

\subsection{Perception on the use of SNSs}

There have been researches centered on the idea of students using SNSs to develop their English-language writing skills. According to Vikneswaran and Krish (2016), the participants had a positive standpoint that the application of the Facebook page enhanced their writing skills. It was also discovered that the 
students could produce a piece of writing without any feeling pressured from the teacher and peers. Similar to this study, where a large number of respondents approved that Facebook had certainly facilitated language learning in the online atmosphere (Shukor, 2015). Besides that, according to Sakkir, Rahman, \& Salija (2016), they found that the students have showcased an excellent attitude and inclination to apply SNSs in the writing classroom. Meanwhile, according to a study conducted by (Khoiriyah \& Safitri Sa'adah, 2017), student impressions of the use of Twitter in the English language were found to be optimistic.

Whereas, according to Ismail(2019), he found that there were $74 \%$ of the respondents agree that the inculcation of social media within the classroom context established positive consequences on the learning activity. Consequently, by referring to Alnatsheh, (2018), the researchers have concluded that SNSs, have huge positive consequences for the educational process, and that flexibility can be achieved. Furthermore, according to findings (Yunus, Salehi \& Nordin, 2012), most respondents showed affirmative acceptability that the use of the cellular phone in class could improve their performance during learning and teaching.

Furthermore, to measure the perception of SNSs, it involves the functionality of the apps and websites itself. The famous theory to measure and relate it was the Technology Acceptance Model (TAM) by Davis in 1989. According to Robert (2008), he defined perception as the process of recognizing, organizing, and interpreting individual perceptions. Technology Acceptance Model, also known as TAM, is a prominent research model to anticipate the application and approval of information systems and technology by individual users. TAM could assist in developing a questionnaire as to measure; (i) usefulness, (ii) ease of use (iii) ease of learning, and (iv) satisfaction. According to Davis (1989), perceived usefulness refers to what extent a particular individual will upgrade his or her work efficiency using a particular technology. Whereas, perceived ease of use indicates the level of the individual belief in employing the precise system would be exempt from any exertion. As quoted in Davis (1989), ease of use and ease of learning are similar and associated with one another (Roberts and Moran, 1983).

Therefore, it is possible to inculcate the use of SNS in the class for English writing lessons by considering the experience and perception in various aspects.

\subsection{Vygotsky's Sociocultural theory}

The other theory for this study is Vygotsky's Sociocultural theory as it involves relationships and connections within the community. According to Jalaluddin, Yunus, and Yamat(2018), Vygotsky's Sociocultural theories attempt to comprehend the social context of development. Jalaluddin, Yunus, and Yamat (2018) explained that the theory emphasizes on in what way an individual child comes to comprehend his/her world through communications with more proficient individuals in cooperative societies. Likewise, according to Allazzam(2015), he described Dewey's believed that learning was dynamic, and he believed that children should attend the school as to practice with others in a community that provide them experiences to share with a society like students should participate in real-life and build a linking between what they have experienced and what they learned in school. Allazzam (2015) also added 
regarding Vygotsky's theory that community plays a significant part in the learning process, primarily through parents', teachers', and tutors' interaction. The statement is similar to Zainuddin, Abdullah, \& Downe, (2011) where they simplified that Vygotsky's social-cultural theory has been extensively denoted by learning societies such as teachers, lecturers, researchers, and students for his famous study on cognitive theoretical within the zone of proximal development to accomplish the capacity expansion for the learners. Meanwhile, according to Hashim et al. (2018), The socio-cultural Vygotsky theory of human knowledge sets learning as the social conceptual model and the beginning of human intelligence civilisations or societies.

\section{Methodology}

\subsection{Research Design}

This research primarily aims to investigate the perception of undergraduates on the use of SNSs to improve the writing skills of the English language. Second, the researcher attempts to classify the preferences of the SNS among students of undergraduates. With regard to obtaining the results, the holistic views of the analysis are achieved using jointly quantitative and qualitative methods. This method is central in the study' $\mathrm{s}$ goals because it provides insight into the pedagogical approach to English, particularly English writing, which currently serves as a means of teaching and learning. This approach is also useful for respondents to express their views and strengthen English writing skills.

\subsection{Sampling}

In this research, purposive sampling was adopted. The samples' selection requirements were among undergraduates' students that are compulsory to enroll in an English course in the respective university. Another requirement was the foundation students that require to take MUET( Malaysia University English Test). The students are required to write reports, assignments, and essays in English. Hence, these samples are significant to the objectives of the study. Two separate universities: the University of Mara, Shah Alam, and University Technology Petronas, Perak, Malaysia, have been selected as the respondents of this research. The respondents were from different departments, including the Faculty of Engineering, the Faculty of Information and Technology, Faculty of Dentistry, the Faculty of Business Management, and the Faculty of Health Sciences. In total, 118 respondents participated in this study.

\subsection{Research Instruments}

As to garner the data, there were two main instruments used, which are closeended questionnaires and open-ended questions for the respondents. The questionnaire survey was divided into three different parts which were Part A, Part B, and Part C.

Part A involved close-ended questions on demographic details, and part B was about the perceptions of undergraduates of the use of SNSs to improve skills in English and the preferences of SNSs to practice English writing, and part C was primarily for the open-ended question. Part $\mathrm{C}$ was open-ended questions in relation to whether it is beneficial to use SNSs for the learning and practice of English writing, and the second question was whether the use of SNSs could be 
beneficial for English writing skills. The third questions are for the respondent to justify the reasons for SNSs' preferences. Two categorical questions were taken, and 30-items were adapted from previous, relevant research from 'Social media and its impact on students' writing skills' (2018), as well as 'the view of ESL students on the use of Facebook as a collaborative writing platform for enhancing writing performances' (Shukor,2015).

\subsection{Reliability and validity}

Subsequently, the questionnaire was reviewed by the knowledgeable and expert lecturer in the fields of education and social media who examined the face and content validity of the items. As to further validating the research instrument, a pilot study has been carried out with 30 Malaysian undergraduate students in the local university, and the SNSs engagement scale revealed an acceptable internal consistency, with a Cronbach Alpha coefficient reported of .859. Generally, according to Taber (2017), a Cronbach's alpha of .70 was considered as indicative of acceptable reliability. Meanwhile, it could practice that the acceptable values for Cronbach Alpha are from .070 to 0.95 (Tavakol \& Dennick, 2011). Thus, from the values obtained, the items in the instrument can be used for the actual study. Purposive sampling was employed to collect data among undergraduate students. Altogether, the real sample involved is 118 respondents among undergraduates' students from University Technology Mara ( UiTM) and University Technology Petronas (UTP). Data collected are then presented using descriptive analysis, which includes mean score, frequency, and percentage. Qualitative and quantitative were used to analyze the data collected.

\subsection{Data Analysis and procedure}

Apart from the three sections of close-ended questions that comprised the demographic information and also the perception of the usage of SNS in improving English writing skills, and $\mathrm{SNS}^{\prime}$ preferences to practice English writing, there were three open-ended questions added to support the close-ended questions broadly. As to analyze the data, percentages, frequency, and mean were used to describe the quantitative data and triangulate with the qualitative data obtained. The findings and discussions were set apart, following the significant objectives of this study. The results were divided following the themes and research constructs, which were the perception of personal use, academic, and functionality. Then, it was followed by further discussion from the results. Meanwhile, for the procedure, the researcher provided the concern letter and gave it to the selected universities for permission and concern purposes. The lecturers of the selected faculty were also aware and agreed upon the study conducted. The information about the respondents was kept enclose to the researcher. The questionnaires were distributed after the pilot study has been conducted.

\section{Results}

The results were described following the demographic information of the respondents, research objective one, and research objective two. Firstly was regarding the demographic information. Then followed by the explanations of the results obtained that emerged into different themes, which are personal purposes, academic purposes, and functionality. These themes could help to get a better 
picture of the results gained.

Table 4.1 The structure of the respondents for the categories mentioned above.

\begin{tabular}{cccc}
\hline Demographic Info & Category & Frequency $\mathbf{( F )}$ & Percentage (\%) \\
\hline \multirow{2}{*}{ Gender } & Male & 32 & 27.1 \\
\cline { 2 - 4 } Age Group & Female & 86 & 72.9 \\
& 18 to 23 years old & 117 & 99.2 \\
\cline { 2 - 4 } & 24 to 29 years old & 1 & 8 \\
\hline University & UiTM & 69 & 58.5 \\
\cline { 2 - 4 } Faculty & UTP & 49 & 41.5 \\
& $\begin{array}{c}\text { Business and } \\
\text { management }\end{array}$ & 10 & 8.5 \\
\cline { 2 - 4 } & $\begin{array}{c}\text { Information and } \\
\text { Technology }\end{array}$ & 20 & 16.9 \\
\cline { 2 - 4 } & Engineering & 53 & 44.9 \\
\cline { 2 - 4 } & Health Sciences & 6 & 24.1 \\
\cline { 2 - 4 } & Dentistry & 29 & \\
\hline
\end{tabular}

Table 4.1 displays the respondents' demographic information, including gender, age group, university, and faculty. A total of 86 (72.9\%) females, followed by 32 $(27.1 \%)$ males involved in the survey. The overall figure for the age range between 18 years to 23 years were $117(99.2 \%)$, with subsequent $1(8 \%)$ for the age range between 24 to 29 years old. A total of $69(58.5 \%)$ of the respondents were from the University of Technology Mara (UiTM), and they were pursuing their bachelor's degree in the respective university. Meanwhile, there were $49(41.5 \%)$ from the University of Technology Petronas, and they were the foundation studies student who is preparing for the continuation of studies for a bachelor's degree.

The respondents were among the different fields of study and faculty. Most of the respondents were from the faculty of Engineering, which were $53(44.9 \%)$. The second highest was from the Faculty of Dentistry, which was $29(24.6 \%)$. There were $20(16.9 \%)$ from faculty of Information of Technology, $10(8.5 \%)$ from faculty of Business and Management, and $6(5.1 \%)$ from faculty of Health Sciences.

As to gauge the respondents' English language proficiency, their MUET results are also part of the essential data for this study.

Table 4.2 Respondents' reported MUET results

\begin{tabular}{ccc}
\hline MUET Band & Frequency $(\mathrm{F})$ & Percentage $(\%)$ \\
\hline Band 1 & - & - \\
Band 2 & 6 & 5.1 \\
Band 3 & 27 & 22.9 \\
Band 4 & 31 & 26.3 \\
Band 5 & 5 & 4.2 \\
Band 6 & - & - \\
\hline Not yet sitting for the & 49 & 41.5 \\
examination & & \\
\hline
\end{tabular}


Table 4.2 shows a total of $31(22.9 \%)$ of the respondents achieved band 4 for their MUET results, and it indicates they are the modest English users. There was 27 $(22.9 \%)$ achieved band 3 , followed by $6(5.1 \%)$ band 2 and $5(4.2 \%)$ for band 5 . From the results reported it to indicate that mostly had an average English proficiency. Meanwhile, There were 49(41.6\%) have not taken and sat for the examination, which recorded $49(41.5 \%)$. They were among foundation studies student from UTP.

Table 4.3 shows the mean score interpretation for each item to respond to the research objective, which is undergraduates' student perception on the use of SNSs in improving English writing skills.

Table 4.3 Mean Score Interpretation

\begin{tabular}{cc}
\hline Mean Score & Phase \\
\hline $1.00-2.33$ & Low \\
\hline $2.34-3.67$ & Medium/average \\
\hline $3.68-5.00$ & High \\
\hline \multicolumn{2}{c}{ Landell(1997) }
\end{tabular}

Research objective one;

to investigate the students' perception of the use of SNSs in improving English writing skills.

Table 4.4 Frequency of perception on the personal use of SNSs

\begin{tabular}{|c|c|c|c|c|c|c|c|}
\hline Category & Statement & SD & $\mathrm{D}$ & $\mathrm{N}$ & A & SA & Mean \\
\hline \multirow{6}{*}{ Personal } & $\begin{array}{l}\text { I feel comfortable to } \\
\text { practice English writing on } \\
\text { SNSs with my friends. }\end{array}$ & $\begin{array}{c}1 \\
(8 \%)\end{array}$ & $\begin{array}{c}23 \\
(19.5 \%)\end{array}$ & $\begin{array}{c}51 \\
(43.2 \%)\end{array}$ & $\begin{array}{c}33 \\
(28 \%)\end{array}$ & $\begin{array}{c}10 \\
(8.5 \%)\end{array}$ & 3.24 \\
\hline & $\begin{array}{l}\text { I feel confident to use } \\
\text { English on SNSs. }\end{array}$ & $\begin{array}{c}2 \\
(1.7 \%)\end{array}$ & $\begin{array}{c}11 \\
(9.3 \%)\end{array}$ & $\begin{array}{c}31 \\
(26.3 \%)\end{array}$ & $\begin{array}{c}49 \\
(41.5 \%)\end{array}$ & $\begin{array}{c}25 \\
(21.2 \%)\end{array}$ & 3.71 \\
\hline & $\begin{array}{l}\text { I feel good to use English } \\
\text { language on SNSs. }\end{array}$ & $\begin{array}{c}2 \\
(1.7 \%)\end{array}$ & $\begin{array}{c}16 \\
(13.6 \%)\end{array}$ & $\begin{array}{c}43 \\
(36.4 \%)\end{array}$ & $\begin{array}{c}45 \\
(38.1 \%)\end{array}$ & $\begin{array}{c}12 \\
(10.2 \%)\end{array}$ & 3.42 \\
\hline & $\begin{array}{l}\text { I felt comfortable having } \\
\text { my peers read my writing } \\
\text { in English through the SNS. }\end{array}$ & 0 & $\begin{array}{c}4 \\
(3.4 \%)\end{array}$ & $\begin{array}{c}14 \\
(11.9 \%)\end{array}$ & $\begin{array}{c}41 \\
(34.7 \%)\end{array}$ & $\begin{array}{c}59 \\
(50 \%)\end{array}$ & 4.31 \\
\hline & $\begin{array}{c}\text { I felt comfortable giving } \\
\text { feedback to my peers on } \\
\text { their writing in English } \\
\text { using SNS. }\end{array}$ & 0 & $\begin{array}{c}11 \\
(9.3 \%)\end{array}$ & $\begin{array}{c}47 \\
(39.8)\end{array}$ & $\begin{array}{c}43 \\
(36.4 \%)\end{array}$ & $\begin{array}{c}17 \\
(14.4 \%)\end{array}$ & 3.56 \\
\hline & $\begin{array}{l}\text { I felt comfortable posting } \\
\text { ideas or opinions on SNS. }\end{array}$ & $\begin{array}{c}1 \\
(8 \%)\end{array}$ & $\begin{array}{c}6 \\
(5.1)\end{array}$ & $\begin{array}{c}45 \\
(38.1 \%)\end{array}$ & $\begin{array}{c}50 \\
(42.4 \%)\end{array}$ & $\begin{array}{c}16 \\
(13.6 \%)\end{array}$ & 3.63 \\
\hline \multicolumn{2}{|c|}{ Total Mean Score } & & & & & & 3.65 \\
\hline
\end{tabular}

Table 4.4 displays the frequency of perception on the use of SNSs for personal purposes. It was found that the highest mean score for personal use is for the item I felt comfortable having my peers read my writing in English through the SNS, which is $(\mathrm{M}=4.31)$. From the item, it could also be supported by the open-ended section where the respondent stated that "yes, because when people give feedbacks 
about my writing, it can be my guider to improve myself." Meanwhile, one of the respondents stated that, yes, because it is a place we can be comfortable with the English language and able to make mistakes. As quoted in (Yunus, Zakaria, \& Suliman, 2019), the students should be provided with a tool that they can feel comfortable to achieve the task assigned (Allen and Tay, 2012). By looking at the use of technology (Sorensen, 2013) stated that the students are more comfortable using technology for language learning.

The second highest for personal use is $(\mathrm{M}=3.71)$ for the item I felt confident to use English on SNSs. According to research by (Hashim et al., 2018), it was found that $48(52.7 \%)$ of the respondents agree that they feel confident to use English on Social Media. One of the respondents stated that "yes because it makes me even more confident to talk and write in English, plus now I can learn English anywhere and anytime that I wanted."

Besides that, the average mean score for perception on the personal use of SNSs is $(\mathrm{M}=3.63)$ for the item I feel comfortable posting ideas or opinions on SNS. From the findings above, it indicated that the respondents have positives perceptions of the use of SNSs concerning the application of English for writing the contents.

Table 4.5 Frequency of perception on the use of SNSs for Academic purposes

\begin{tabular}{|c|c|c|c|c|c|c|c|}
\hline Category & Statement & SD & $\mathrm{D}$ & $\mathrm{N}$ & A & SA & Mean \\
\hline \multirow{9}{*}{$\begin{array}{l}\text { Academic } \\
\text { Purposes }\end{array}$} & $\begin{array}{l}\text { I think online chatting } \\
\text { helps me to improve my } \\
\text { English writing. }\end{array}$ & 0 & $\begin{array}{c}1 \\
(8 \%)\end{array}$ & $\begin{array}{c}16 \\
(13.6 \%)\end{array}$ & $\begin{array}{c}71 \\
(60.2 \%)\end{array}$ & $\begin{array}{c}30 \\
(25.4 \%)\end{array}$ & 4.10 \\
\hline & $\begin{array}{l}\text { I think SNSs (writing } \\
\text { status, comment) helps me } \\
\text { to improve my writing. }\end{array}$ & 0 & $\begin{array}{c}3 \\
(2.5 \%)\end{array}$ & $\begin{array}{c}24 \\
(20.3 \%)\end{array}$ & $\begin{array}{c}72 \\
(61 \%)\end{array}$ & $\begin{array}{c}19 \\
(16.1 \%)\end{array}$ & 3.91 \\
\hline & $\begin{array}{l}\text { I think SNSs language } \\
\text { influence my formal } \\
\text { writing positively. }\end{array}$ & $\begin{array}{c}2 \\
(1.7 \%)\end{array}$ & $\begin{array}{c}7 \\
(5.9 \%)\end{array}$ & $\begin{array}{c}35 \\
(29.7 \%)\end{array}$ & $\begin{array}{c}63 \\
(53.4 \%)\end{array}$ & $\begin{array}{c}11 \\
(9.3 \%)\end{array}$ & 3.63 \\
\hline & $\begin{array}{l}\text { I use SNSs to enhance my } \\
\text { English writing skill. }\end{array}$ & 0 & $\begin{array}{c}3 \\
(2.5 \%)\end{array}$ & $\begin{array}{c}25 \\
(21.2 \%)\end{array}$ & $\begin{array}{c}75 \\
(63.6 \%)\end{array}$ & $\begin{array}{c}15 \\
(12.7 \%)\end{array}$ & 3.86 \\
\hline & $\begin{array}{l}\text { I use SNSs for learning } \\
\text { and academic purposes. }\end{array}$ & 0 & $\begin{array}{c}4 \\
(3.4 \%)\end{array}$ & $\begin{array}{c}36 \\
(30.5 \%)\end{array}$ & $\begin{array}{c}61 \\
(51.7 \%)\end{array}$ & $\begin{array}{c}17 \\
(14.4 \%)\end{array}$ & 3.77 \\
\hline & $\begin{array}{l}\text { I prefer to write in English } \\
\text { when using SNSs. }\end{array}$ & 0 & 0 & $\begin{array}{c}33 \\
(28 \%)\end{array}$ & $\begin{array}{c}49 \\
(41.5 \%)\end{array}$ & $\begin{array}{c}36 \\
(30.5 \%)\end{array}$ & 4.03 \\
\hline & $\begin{array}{l}\text { I believe that SNSs is the } \\
\text { platform to learn. }\end{array}$ & 0 & $\begin{array}{c}1 \\
(8 \%)\end{array}$ & $\begin{array}{c}24 \\
(20.3 \%)\end{array}$ & $\begin{array}{c}66 \\
(55.9 \%)\end{array}$ & $\begin{array}{c}27 \\
(22.9 \%)\end{array}$ & 4.01 \\
\hline & $\begin{array}{l}\text { I found it easy to complete } \\
\text { my essay using SNS }\end{array}$ & 0 & $\begin{array}{c}10 \\
(8.5 \%)\end{array}$ & $\begin{array}{c}35 \\
(29.7 \%)\end{array}$ & $\begin{array}{c}58 \\
(49.2 \%)\end{array}$ & $\begin{array}{c}15 \\
(12.7 \%)\end{array}$ & 3.66 \\
\hline & $\begin{array}{l}\text { I prefer writing on SNS } \\
\text { than writing in classroom } \\
\text { discussion context because } \\
\text { it saves my time. }\end{array}$ & $\begin{array}{c}3 \\
(2.5 \%)\end{array}$ & $\begin{array}{c}14 \\
(11.9 \%)\end{array}$ & $\begin{array}{c}44 \\
(37.3 \%)\end{array}$ & $\begin{array}{c}40 \\
(33.9 \%)\end{array}$ & $\begin{array}{c}17 \\
(14.4 \%)\end{array}$ & 3.46 \\
\hline
\end{tabular}

Table 4.5 shows the frequency of perception on the use of SNSs for academic purposes. The highest mean score is $(M=4.10)$, which is for the item I think online 
chatting helps me to improve my English writing. It is followed by another high mean score which is (M-3.91) for the item I think SNSs (writing status, comments) help me to improve my English writing. One of the respondents mentioned that, "yes, because not only I could improve my English skills, but also have some good times with my friends." Besides that, one of the respondents stated that "yes, because we use SNSs everyday, so the more we use it, the more we can improve our English writing skills." Similar to a study conducted by (Hashim et al., 2018) where they found that $60(66.0 \%)$ agree that online chatting helps to improve English writing. By looking at the applying media in education, it will not only improve their language, but they also easy to comprehend the lessons. (Lubis, Embi, Yunus, Wekke, \& Nordin, 2009).

Besides that, by looking at the perspective as using SNSs as a platform to learn, it has a high mean score, which is $(\mathrm{M}=4.01)$. The respondents also tend to use SNSs to improve English writing, which has a high mean score $(\mathrm{M}=3.81)$. One of the respondents agrees that "yes, because the sites are like a platform for me to practice."Moreover, one of the respondents also stated that "yes, it helps me to enhance my vocab as well as my capability to write essays."

Meanwhile, by looking at their intention, there is also a high mean score $(\mathrm{M}=3.77)$ for the item I use SNSs for learning and academic purpose. From the responses, it could be said that the respondents portrayed positive perception and attitude to the utilization of SNSs in improving English writing. It also displayed the potential of SNSs in incorporating in teaching and learning process. (Villarruel, Lima, Rivera, \& Morán, 2017) mentioned that from the positive attitude of students towards technological tools are the aspects that will promote Social Networks in the educational development.

Table 4.6 Frequency of SNS use for perception on functionality

\begin{tabular}{|c|c|c|c|c|c|c|c|}
\hline Category & Statement & SD & $\mathrm{D}$ & $\mathrm{N}$ & A & SA & Mean \\
\hline \multirow{5}{*}{ Functionality } & $\begin{array}{l}\text { My friends will correct my } \\
\text { mistakes on my status or } \\
\text { comment. }\end{array}$ & $\begin{array}{c}4 \\
(3.4 \%)\end{array}$ & $\begin{array}{c}19 \\
(16.1 \%)\end{array}$ & $\begin{array}{c}33 \\
(28 \%)\end{array}$ & $\begin{array}{c}51 \\
(43.2 \%)\end{array}$ & $\begin{array}{c}11 \\
(9.3 \%)\end{array}$ & 3.89 \\
\hline & $\begin{array}{l}\text { I am conscious about } \\
\text { grammatical structure } \\
\text { when I write on SNSs. }\end{array}$ & $\begin{array}{c}1 \\
(8 \%)\end{array}$ & $\begin{array}{c}3 \\
(2.5 \%)\end{array}$ & $\begin{array}{c}19 \\
(16.1 \%)\end{array}$ & $\begin{array}{c}56 \\
(47.5 \%)\end{array}$ & $\begin{array}{c}39 \\
(33.1 \%)\end{array}$ & 4.09 \\
\hline & $\begin{array}{l}\text { I am conscious about } \\
\text { spelling when I write on } \\
\text { SNSs. (chat, comment and } \\
\text { write) }\end{array}$ & $\begin{array}{c}1 \\
(8 \%)\end{array}$ & $\begin{array}{c}2 \\
(1.7 \%)\end{array}$ & $\begin{array}{c}13 \\
(11 \%)\end{array}$ & $\begin{array}{c}62 \\
(52.5 \%)\end{array}$ & $\begin{array}{c}40 \\
(33.9 \%)\end{array}$ & 4.17 \\
\hline & $\begin{array}{l}\text { I am conscious about } \\
\text { punctuation when I write } \\
\text { on SNSs (Chat, comment } \\
\text { and write status }\end{array}$ & 0 & $\begin{array}{c}6 \\
(5.1 \%)\end{array}$ & $\begin{array}{c}31 \\
(26.3 \%)\end{array}$ & $\begin{array}{c}52 \\
(44.1 \%)\end{array}$ & $\begin{array}{c}29 \\
(24.6 \%)\end{array}$ & 3.86 \\
\hline & $\begin{array}{l}\text { Peer comment on the SNS } \\
\text { really helped me to } \\
\text { improve my writing in } \\
\text { English. }\end{array}$ & 0 & $\begin{array}{c}4 \\
(3.4 \%)\end{array}$ & $\begin{array}{c}34 \\
(28.8 \%)\end{array}$ & $\begin{array}{c}64 \\
(54.2 \%)\end{array}$ & $\begin{array}{c}16 \\
(13.6 \%)\end{array}$ & 3.78 \\
\hline Total Mean Sc & ore & & & & & & 3.95 \\
\hline
\end{tabular}


Table 4.6 shows the frequency of SNS use for the perception of functionality. The highest mean score is $(\mathrm{M}=4.17)$, which is for the item I am conscious about spelling when I write on SNSs (chat, comment, and write). It is not only looking at their consciousness of spelling, but the users also commented on the features that appear in the SNSs, and mobile phones. There is also a high mean score, for I am conscious of grammatical structure when I write on SNSs, which is $(\mathrm{M}=4.09)$. The respondents also agree that I am conscious of punctuation when I write on SNSs, which has a high mean score $(\mathrm{M}=3.86)$. One of the respondents mentioned that "yes, because Social Networking Site gives me time to think twice and wisely before posting anything. I will be able to check for any grammar or spelling mistakes, especially when my auto-correct keyboard is turned on". Furthermore, according to (Abd et al., 2016), it was found that the spell-check feature correction could help the users to lessen their spelling mistakes.

The second highest mean score is $(M=3.89)$ for the item my friends will correct my mistakes on my status or comment. It has been mentioned by one of the respondents, "yes, people understand what I want to tell about, and if I do a mistake they will correct me." One of the respondents also mentioned that "yes, because people will correct us and we will improve ourselves to write or post something on SNSs without any grammar error." Significantly, there is also a high mean score for peer comment on SNS helped me to improve my writing in English, which is $(\mathrm{M}=3.78)$. The findings are similar to a study conducted by (Hashim et al., 2018), where there are $65(71.4 \%)$ of the students agree that their friends will correct the mistakes, which include spelling and grammatical errors.

Therefore, when the users are aware of the spelling, grammatical structure and have feedback from the other users, it could assist them in improving English writing. Moreover, the process could work simultaneously either from the friends or from the auto-correct or spell-checker function in SNSs.

\section{Research objective two;}

to identify the SNSs' preferences to practice English writing.

Table 4.7 Frequency of SNS preferences in improving English Writing Skills

\begin{tabular}{rlcccccc}
\hline $\begin{array}{r}\text { Social } \\
\text { Media }\end{array}$ & \multicolumn{1}{c}{ Statement } & SD & D & N & A & SA & Mean \\
\hline Facebook & The Social & 14 & 47 & 37 & 13 & 7 & 2.59 \\
& $\begin{array}{l}\text { Networking Site I } \\
\text { prefer for my English }\end{array}$ & $(11.9 \%)$ & $(39.8 \%)$ & $(31.4 \%)$ & $(11 \%)$ & $(5.9 \%)$ & \\
& $\begin{array}{l}\text { Writing practice is } \\
\text { Facebook }\end{array}$ & & & & & & \\
\hline Instagram & The Social & 6 & 13 & 37 & 51 & 11 & 3.41 \\
& $\begin{array}{l}\text { Networking Site I } \\
\text { prefer for my English }\end{array}$ & $(5.1 \%)$ & $(11 \%)$ & $(31.4 \%)$ & $(43.2 \%)$ & $(9.3 \%)$ & \\
& Writing practice is & & & & & & \\
& Instagram & & & & & & \\
\hline YouTube & The Social & 4 & 10 & 26 & 42 & 36 & 3.81 \\
& Networking Site I & $(3.4 \%)$ & $(8.5 \%)$ & $(22.0 \%)$ & $(35.6 \%)$ & $(30.5 \%)$ & \\
prefer for my English & & & & & & \\
Writing practice is & & & & & & \\
YouTube & & & & & & \\
\hline
\end{tabular}




\begin{tabular}{|c|c|c|c|c|c|c|c|}
\hline Blogspot & $\begin{array}{l}\text { The Social } \\
\text { Networking Site I } \\
\text { prefer for my English } \\
\text { Writing practice is } \\
\text { Blogspot }\end{array}$ & $\begin{array}{c}6 \\
(5.1 \%)\end{array}$ & $\begin{array}{c}13 \\
(11 \%)\end{array}$ & $\begin{array}{c}39 \\
(33.1 \%)\end{array}$ & $\begin{array}{c}40 \\
(33.9 \%)\end{array}$ & $\begin{array}{c}20 \\
(16.9 \%)\end{array}$ & 3.47 \\
\hline WhatsApp & $\begin{array}{l}\text { The Social } \\
\text { Networking Site I } \\
\text { prefer for my English } \\
\text { Writing practice is } \\
\text { WhatsApp }\end{array}$ & $\begin{array}{c}2 \\
(1.7 \%)\end{array}$ & $\begin{array}{c}19 \\
(16.1 \%)\end{array}$ & $\begin{array}{c}41 \\
(34.7 \%)\end{array}$ & $\begin{array}{c}43 \\
(36.4 \%)\end{array}$ & $\begin{array}{c}13 \\
(11 \%)\end{array}$ & 3.39 \\
\hline Telegram & $\begin{array}{l}\text { The Social } \\
\text { Networking Site I } \\
\text { prefer for my English } \\
\text { Writing practice is } \\
\text { Telegram }\end{array}$ & $\begin{array}{c}4 \\
(3.4 \%)\end{array}$ & $\begin{array}{c}14 \\
(11.9 \%)\end{array}$ & $\begin{array}{c}51 \\
(43.2 \%)\end{array}$ & $\begin{array}{c}39 \\
(33.1 \%)\end{array}$ & $\begin{array}{c}10 \\
(8.5 \%)\end{array}$ & 3.31 \\
\hline Google+ & $\begin{array}{l}\text { The Social } \\
\text { Networking Site I } \\
\text { prefer for my English } \\
\text { Writing practice is } \\
\text { Google+ }\end{array}$ & $\begin{array}{c}3 \\
(2.5 \%)\end{array}$ & $\begin{array}{c}13 \\
(11 \%)\end{array}$ & $\begin{array}{c}38 \\
(32.2 \%)\end{array}$ & $\begin{array}{c}40 \\
(33.9 \%)\end{array}$ & $\begin{array}{c}24 \\
(20.3 \%)\end{array}$ & 3.58 \\
\hline Tumblr & $\begin{array}{l}\text { The Social } \\
\text { Networking Site I } \\
\text { prefer for my English } \\
\text { Writing practice is } \\
\text { Tumblr }\end{array}$ & $\begin{array}{c}14 \\
(11.9 \%)\end{array}$ & $\begin{array}{c}33 \\
(28 \%)\end{array}$ & $\begin{array}{c}44 \\
(37.3 \%)\end{array}$ & $\begin{array}{c}20 \\
(16.9 \%)\end{array}$ & $\begin{array}{c}7 \\
(5.9 \%)\end{array}$ & 2.77 \\
\hline Twitter & $\begin{array}{l}\text { The Social } \\
\text { Networking Site I } \\
\text { prefer for my English } \\
\text { Writing practice is } \\
\text { Twitter }\end{array}$ & $\begin{array}{c}6 \\
(5.1 \%)\end{array}$ & $\begin{array}{c}15 \\
(12.7 \%)\end{array}$ & $\begin{array}{c}25 \\
(21.2 \%)\end{array}$ & $\begin{array}{c}35 \\
(29.7 \%)\end{array}$ & $\begin{array}{c}37 \\
(31.4 \%)\end{array}$ & 3.69 \\
\hline
\end{tabular}

Table 4.7 shows the SNSs' preferences to practice English writing skills among undergraduates' students. The highest mean score is 3.81, which is for the item The SNSs I prefer for my English writing practice is YouTube. The result is parallel to one of the studies where the highest mean score for the item SNSs I would use for practice English language is Youtube, which is 4.35 ((Villafuerte \& Romero, 2017). Apart from that, (AlShoaibi \& Shukri, 2017) also discovered that male students commonly used YouTube. By referring to the respondents' perspective, it was said that "I prefer YouTube because most of the viewers are foreigners, and I am forced to write in English."

Interestingly, one of the respondents mentioned that "I prefer YouTube because YouTube mostly contains full of good videos in English that I can learn from it and test my listening skill. So from that, I can gain useful information for my writing". As to look at the potential of YouTube in improving English language skills, it was found that the results are gradually increasing after the use of YouTube to teach social expression (Raj, Ann, Subramaniam, \& Yunus, 2019).

The second highest mean score is $(M=3.69)$, which is for the item; the Social Networking Site I prefer for my English writing is Twitter. The result is similar to a study by (Ezumah, 2013) where they found that there are $67 \%$ of the respondents 
prefer to use Twitter. It was also found that the users ranked Twitter as the highest for a 24-hour log on. Meanwhile, by referring to the open-ended section, the users mentioned that "I prefer Twitter, of course because Twitter usually spread many useful information or oftenly using thread as to educate people." One of the respondents also mentioned that "I learned to so much from Twitter because it requires you to read. You read because you want to know the information". It was found from another study that the use of Twitter for informational purposes has a positive response from the respondents (Hughes, Rowe, Batey, \& Lee, 2012).

Meanwhile, the average mean score is $(\mathrm{M}=3.58)$ for Google+ followed by $(\mathrm{M}=3.47)$ for Blogspot, $(M=3.41)$ for Instagram, $(M=3.39)$ for WhatsApp, $(M=3.31)$ for Telegram, $(\mathrm{M}=2.77)$ for Tumblr and only $(\mathrm{M}=2.59)$ for Facebook. Blogspot is one of the SNSs that solely help the users to practice English writing. According to (Said et al., 2013), it was found that blogging assists the users to improve their English writing and increase their motivation. There is no lowest mean score for the SNSs preferences to practice English writing. Therefore, it is still possible to use other SNSs to practice English writing.

\section{Discussion}

Results obtained helped to shows that many students who use SNSs are among the 18-23 years of age. This particular knowledge is parallel to most SNSs users in Generation Z. As quoted in (Aziz, Hashim, \& Yunus, 2019), Generation Z is among the children that grow up with the Millenials, where they are familiar with the technology. Therefore, this group age employed technology and Social Media since at a very young age (Aziz et al., 2019). Findings from the data obtained also show that most of the respondents are female. It was quite surprising, as most of the respondents were from the Faculty of Engineering, which are 53(44.9\%), where most of them were male students. However, one study showed that male students' perceptions and attitudes towards the utilization of SNSs have been more positive than women with negative perception and attitude in learning English (AlShoaibi \& Shukri, 2017)

In regards to the perception of the use of SNSs for different purposes, the highest was because of the functionality, which was $(\mathrm{M}=3.95)$, followed by academic purposes, which were $(M=3.82)$ and for social purposes which were $(M=3.65)$. One of the surveys conducted by (Villafuerte \& Romero, 2017), found that there was a high mean score, which was $(\mathrm{M}=4.44)$, where the respondents agree that the functionality of the SNSs should be used for English language practice in the higher learning institution. The significant results display that most of the respondents are aware of the spelling, grammar, and punctuation when they are starting to write on their profile. Besides that, there is also auto-correct from the profile, which helps the users to correct their mistakes. Therefore, from their consciousness and assistant from the auto-correct feature, it could minimize their mistake. From that process, the users are allowed to learn how to write appropriately. (Rimbar, 2019) discovered that the function of spell-checker could assist the learners in improving their spelling and dictation. According to a survey conducted by (Rahimi, Gholizadeh, \& Shahryari, 2019), Male and female students have positive perceptions about the use of automatic English language correction software. The findings revealed correlates to the benefits of SNS's features and 
functionality, where it encourages innovation, teamwork, and accessibility throughout the internet (Alnatsheh, 2018). Hence, the functionality of SNSs could also contribute to the positive perception in the use of SNSs in improving English writing skills instead of consciousness and helps from friends.

Regarding the perception of the use of SNSs for academic purposes, the respondents display a positive perception towards the purpose. The results display that the users do not only use SNSs for personal use but also to seek information and knowledge. The users also tend to share their information and knowledge with the other users. The results indicate a significant with the perceived usefulness. According to Davis (1989), perceived usefulness refers to the degree to which a specific person can enhance his work performance through a particular system. For instance, Using Twitter has helped participants to develop their understanding of the fundamentals of writing in English more than using Facebook or vice versa (Mohammad et al., 2018). Besides that, (Hussein, Omar, \& Zayadah, 2016) added that the application of IT is not limited to sharing knowledge but also contributes to the development of teaching and learning to be more flexible, particularly for educators and students. Meanwhile, (Al-Rahmi \& Zeki, 2017) stated that Social Media is known as the platform to relocate the information and knowledge among the communities and the educators. Thus, it is beneficial for the users to get the knowledge from SNSs, and at the same time, the users could practice English writing with the opportunity given.

Next is regarding the perception of the use of SNSs for personal and social purposes. Most of the respondents are comfortable to use SNSs to post ideas, feedback sharing among the other users when they use English to write. From the perspective, it could influence their daily attitude in the use of SNSs and assist the process of learning and teaching English writing. The activities that happened also could develop collaborative learning where it could benefit the users. According to (Zainuddin et al., 2011), the applications from websites enable the users to update profiles, active discussion via comment, and chat tool as well as giving feedback throughout the activities. It has been discovered that feedback from peers can increase students' critical thinking, level of confidence, creativity, increase the level of motivation, and improve their assignments (Farrah, 2012). This method and development are in line with the theory of learning in which, according to Hashim et al. (2018), Vygotsky's socio-cultural theory defines learning as a social process and the commencement of the human intelligence or society.

Furthermore, by looking at the SNSs preferences to practice English writing, it was found that YouTube has the highest mean. YouTube is useful as it integrates listening, speaking, reading, and writing. The users can listen and read from the videos displayed then could write on the comment sections. The users are not restricted to only watch and listen only but also can write any comments there. In addition, One of the research on the usage of YouTube as a learning medium has shown that there has been a substantial increase in the number of related questions in post-test results, thereby indicating comprehension of so-called social speech. In conclusion, YouTube visualization is an excellent resource that can keep participants informed and want to know more about the language (Raj et al., 
2019).

The second highest mean score is Twitter. Twitter is famous for the use of threads to display any information. According to the action research carried out by (Alqunayeer, 2016), The findings indicate that since the use of Twitter in the teaching and learning process, the vocabulary of the students has increased. Apart from that, (Khoiriyah \& Safitri Sa'adah, 2017) discovered the respondents believe that Twitter is a valuable online medium for English learning and helps students increase their confidence in the application of English in their daily lives.

Generally, the results of the research indicate that the use of SNSs to improve the English skills of undergraduate students is positive. It is imperative to consider the students' perspective in the inculcation of SNSs in improving English writing skills. Moreover, (Villarruel et al., 2017) stated that the usage of digital social networks as a technical instrument that is regarded as useful and beneficial for teaching and learning in higher education institutions needs to be reconsidered.

\section{Conclusion}

In reliance on the findings, it could be inferred that there are positive perceptions from the undergraduate students in the usage of SNS as a tool to practice English writing. From the respondents' responses, it also indicates that the utilizing of SNS in the classroom teaching and learning activities could assist them in enhancing the English writing skills. Furthermore, English writing teaching and learning are not limited to the same group but also globally, whereby it is applicable to gain more experience and feedbacks. Besides, the use of SNS has the potential to be an effective cybergogy, as it requires close interaction between learners and educators. The use of SNSs is also favorable to numerous group range. While it can be used as a medium for teaching and learning. Consequently, more research on the effectiveness of the use of SNSs in English writing should be carried out to provide a more detailed overview. Further studies on the use of SNSs in other components, such as reading, speaking, and listening, also should be conducted.

\section{Implication and recommendation.}

This study, therefore, helps students to practice English writing on different channels. This study also helps educators provide their students with a more engaging and insightful learning platform. As a result of Pandemic Covid-19, which impacted learning and education systems globally, SNS and LMS could become the platform for learning and teaching purposes. This implementation also provides a great opportunity for the parents to monitor and assist their children's learning growth. In the meantime, the researcher has an excellent opportunity to monitor the progress of the framework for improvisation and conduct further research. This study can assist the process of uncovering critical areas that the researchers are looking for to expand the educational development. 


\section{Acknowledgments}

This research was supported by the grant from the Faculty of Education, Universiti Kebangsaan Malaysia, GG-2018-001 and GG-2019-009. I appreciate acknowledging the support of grant contributors to the accomplishment of this manuscript.

\section{References}

Abd, M., Ali, E., Ahmed, S., \& Arabia, S. (2016). Using Facebook to Develop Grammar Discussion and Writing Skills in English as a Foreign Language for University Student. David Publishing Company, From Knowledge to Wisdom, 13(12), 932-952. https://doi.org/10.17265/1539-8072/2016.12.004

Al-Rahmi, W. M., \& Zeki, A. M. (2017). A model of using social media for collaborative learning to enhance learners' performance on learning. Journal of King Saud University - Computer and Information Sciences, 29(4), 526-535. https://doi.org/10.1016/j.jksuci.2016.09.002

Allazzam, M. (2015). Learning from Dewey and Vygotsky Perspective.International Journal of Scientific \& Engineering Research 6(7), 1854-1867. Retrieved from https://www.ijser.org/onlineResearchPaperViewer.aspx?Learning-fromDewey-and-Vygotsky-Perspective.pdf

Al-Tamimi, M., Al-Khawaldeh, A., Al Natsheh, H., \& Harazneh, A. (2018). The effect of using Facebook on improving English language writing skills and vocabulary enrichment among University of Jordan sophomore students. Journal of Social Sciences(COESERJ-JSS), 7 7(3),

$187-214$ https://doi.org/10.25255/jss.2018.7.3.187.214

Alqunayeer, H. S. (2016). The Impact of Teaching through Twitter on Students ' Vocabulary Learning: A Case Study of Qassim University, 6(2), 35-43. https://doi.org/10.5430/wjel.v6n2p35

AlShoaibi, R., \& Shukri, N. (2017). Foundation Year Students' Perceptions of Using Social Network Sites for Learning English in the Saudi Context. English Language Teaching, 10(6), 60-68. https:// doi.org/10.5539/elt.v10n6p60

Altakhaineh, A. R. M., \& Al-Jallad, M. Z. (2018). The use of twitter and Facebook in teaching mechanics of writing to Arabic-speaking EFL learners. International Journal of Emerging Technologies in Learning, 13(9), 4-14. https://doi.org/10.3991/ijet.v13i09.8457

Aziz, N., Hashim, H., \& Yunus, M. M. (2019). Using Social Media to Enhance ESL Writing Skill among Gen-Z Learners. Creative Education, 10(12), 3020-3027. https://doi.org/10.4236/ce.2019.1012226

Belal, A. (2014). Influence of digital social media in writing and speaking of tertiary level student [Master's Thesis, BRAC University, Dhaka, Bangladesh]. Retrieved from http://dspace.bracu.ac.bd/xmlui/handle/10361/5557

Chandran, Y., Plaindaren, C. J., Pavadai, S., \& Yunus, M. M. (2019). Collaborative Writing: An Integration of Snack Bars and Hi-Five Fingers via Social Media. Creative Education, 10(02), 475-484. https://doi.org/10.4236/ce.2019.102034

Clement, J. (2020). Most popular social networks worldwide as of January 2020, ranked by number of active users. Retrieved from https:// www.statista.com/statistics/272014/global-social-networks-ranked-bynumber-of-users/

Ezumah, B. A. (2013). College Students' Use of Social Media: Site Preferences, Uses and Gratifications Theory Revisited. International Journal of Business and Social Science, 4(5), 27-35. Retrieved from http://ijbssnet.com/journal/index/1879

Farrah, M. (2012). The Impact of Peer Feedback on Improving the Writing skills among 
Hebron University Students. An - Najah Univ. J. Res. (Humanities), 26(1), 179-210. Retrieved from https://journals.najah.edu/media/journals/full_texts/impactpeer-feedback-improving-writing-skills-among-hebron-university-students.pdf

Hashim, H., Yunus, M. M., Ibrahim, N. S. M., Jeri, E. J., Sukr, M. A. M., Ilahi, N. S. N., \& Nor Hassim, M. A. (2018). Social Media and Its Impact on Writing Skills. International Journal of Engineering $\mathcal{E}$ Technology, 7(4.21), 102-105. https://dx.doi.org/10/14419/ijet.v7i4.21.21624

Hughes, D. J., Rowe, M., Batey, M., \& Lee, A. (2012). A tale of two sites: Twitter vs. Facebook and the personality predictors of social media usage. Computers in Human Behavior, 28(2), 561-569. https:// doi.org/10.1016/j.chb.2011.11.001

Hussein, N., Omar, M. K., \& Zayadah, M. A. (2016). IT Usage, Perceived Knowledge Usefulness, Learning Culture and Intention to Share Knowledge among Business Students in a Malaysian Public University. Procedia - Social and Behavioral Sciences, 219, 324-329. https://doi.org/10.1016/j.sbspro.2016.04.039

Ismail, S., Zaim, M, \& Mukhaiyar, M. (2019). Student Perspective in Using Social Media As a Tool in English Language Learning. Advances in Social Science,Education and Humanities Reseearch. Proceedings of the $1^{\text {st }}$ International Conference on Innovation in Education (ICoIE 2018), Padang, Indonesia, 493-497. https://doi.org/10.2991/icoie18.2019.106

Jalaluddin, I.,Yunus, M. M., \& Yamat, H.(2018). ESL Writing; A perspective on Self-Efficacy, Learning and Teaching. Malaysia ,Bangi: Penerbit Universiti Kebangsaan Malaysia.

Khoiriyah, I., \& Safitri Sa'adah, N. (2017). Students ' Perception on the Use of Twitter to Learn English: a Preliminary Study. Social Sciences. Proceedings of the ASEAN Academic Society International Conforence Proceeding Series (AASIC), Thailand, 160165.

Lubis, M. A., Embi, M. A., Yunus, M. M., Wekke, I. S., \& Nordin, N. M. (2009). The application of multicultural education and applying ICT on Pesantren in South Sulawesi, Indonesia. WSEAS Transactions on Information Science and Applications, 6(8), 1401-1411. Retrieved from https://www.researchgate.net/publication/262424447_The_application_of_mul ticultural_education_and_applying_ICT_on_Pesantren_in_South_Sulawesi_Ind onesia

Madini, A., \& Alsubaie, A. (2018).The Effect of Using Blogs to Enhance the Writing Skill of English Language Learners at a Saudi University. Global Journal of Educational Studies, 4(1), 13-30. https:/ / doi.org/10.5296/gjes.v4i1.12224

Malaysian Communications and Multimendia. (2019). Internet Users Survey 2018. Retrieved from https://www.mcmc.gov.my/en/resources/statistics/internetusers-survey.

Malaysian Examniations Council. (2018). MUET Examinations Reports. Retrieved from http:// portal.mpm.edu.my/en/laporan-peperiksaan-stpm-dan-muet-2018

Mohammad, M., Ghazali, N., \& Hashim, H. (2018). Secondary school students' perceptions on the use of Google+ towards improving ESL writing skills. International Journal of Emerging Technologies in Learning, 13(9), 224-238. https://doi.org/10.3991/ijet.v13i09.8479

Özdemir, E., \& Aydın, S. (2015). The Effects of Blogging on EFL Writing Achievement. Procedia - Social and Behavioral Sciences, 199, 372-380. https://doi.org/10.1016/j.sbspro.2015.07.521

Rahimi, M., Gholizadeh, G. R., \& Shahryari, A. (2019). Iranian EFL Learners' Perceptions about Automatic Spelling Correction Software Use for Learning English Spellings: A Study with Focus on Gender. International Journal of English Language $\mathcal{E}$ Translation Studies, 7(1), 68-75. Retrieved from 
http://www.eltsjournal.org/archive/value7\%20issue1/8-7-1-19.pdf

Raj, S. A. P. S., Ann, W. H. T., Subramaniam, P. A. L., \& Yunus, M. M. (2019). Using YouTube as a Platform to Learn Social Expression. Creative Education, 10(2), 288296. https:// doi.org/10.4236/ce.2019.102023

Rimbar, H., \& Government, S. (2019). The Influence of Spell-Checkers on Students' Ability to Generate Repairs of Spelling Errors, Journal of Nusantara, 2(1), 1-12. https://doi.org/10.24200/jonus.vol2iss1pp1-12

Said, N. E. M., Yunus, M., Doring, L. K., Asmi, A., Aqilah, F., \& Li, L. K. S. (2013). Blogging to enhance writing skills: A survey of students' perception and attitude. Asian Social Science, 9(16 ), 95-101. https://doi.org/10.5539/ass.v9n16p95

Sakkir, G., Rahman, Q., \& Salija, K. (2016). Students' Perception on Social Media in Writing Class at STKIP Muhammadiyah Rappang, Indonesia, 6(3), 170-175. https://doi.org/10.5539/ijel.v6n3p170

Shukor, S. S. (2015). ESL Students' Perceptions on The Use of Facebook as A Collaborative Writing Tool in Improving Writing Performance. The Asian Journal of English Language \& Pedagogy, 3, 205-227. Retrieved from https://www.researchgate.net/publication/304024124

Sorensen, M.(2013). Student Attitudes toward Social Media Technology as an Enhancement to Language Acquisition [Master's thesis, Brigham Young University, Provo, Utah, US] Retrieved from https:/ / scholarsarchive.byu.edu/cgi/viewcontent.cgi?article=4782\&context=et d

Taber, K.(2017). The Use of Cronbach' s Alpha When Developing and Reporting Research Instruments in Science Education, 1273-1296. Research In Science Education, 48, 1273-1296. https:// doi.org/10.1007/s11165-016-9602-2

Tavakol, M., \& Dennick, R. (2011). Making sense of Cronbach's alpha. International Journal of Medical Education, 2, 53-55. https://doi.org/10.5116/ijme.4dfb.8dfd

Villafuerte, J., \& Romero, A. (2017). Learners' Attitudes toward Foreign Language Practice on Social Network Sites. Journal of Education and Learning, 6(4), 145. https://doi.org/10.5539/jel.v6n4p145

Villarruel, J. I. B., Lima, M. G. B., Rivera, R. N., \& Morán, J. M. B. (2017). The use of Social Networks by the Students of a Mexican Public University. International Journal of Learning, Teaching and Educational Research, 16(10), 132-148. https://doi.org/10.26803/ijlter.16.10.10

Yunus, M. M.,Hashim, H., Edwin, Ho, K. J. (2019). The "Branches Map" method and ESL students' Motivation in essay writing*. Revista de Ciencias Sociales y Humanidades, 4(19), 286-291. Retrieved from http://revista.religacion.com/index.php/about/article/view/539/459

Yunus, M., Salehi, H., Sun, C. H. U. I., Yong, J., Yen, P., Kwan, L., \& Li, S. U. (2011.). Using Facebook Groups in Teaching ESL Writing. Proceedings of the 2nd International Conference on Arts and Culture (ICAC 11), Zimbabwe, 75-80.

Yunus, M.M., Zakaria, S., \& Suliman, A. (2019).The Potential Use of Social Media on Malaysian Primary Students to Improve Writing. International Journal of Education and Practice, 7(4), 450-458. https://doi.org/10.18488/journal.61.2019.74.450.458

Yunus, M. M., Salehi, H., \& Chenzi, C. (2012). Integrating social networking tools into ESL writing classroom: Strengths and weaknesses. English Language Teaching, 5(8), 4248. https://doi.org/10.5539/elt.v5n8p42

Zainuddin, S. A., Abdullah, A., \& Downe, A. G. (2011). Social Networking Sites For Learning: A Review From Vygotskian Perspective. 2011 International Conference on Telecommunication Technolgoy and Applications, Singapore, 5, 41-46. Retrieved from http://www.ipcsit.com/vol5/7-ICCCM2011-A032.pdf 


\section{Appendix}

\section{Research Instruments (Survey Forms)}

\section{Section A}

Demographic factors

Please tick (/) the relevant box for each of the following:

A1. My gender:

Male

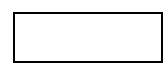

Female

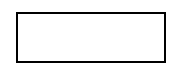

A2. My age group:

18 to 23 yrs

30 to $40 \mathrm{yrs}$

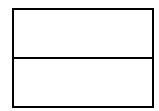

24 to 29 yrs

above 40 yrs

A3. Currently I am doing

Foundation

Undergraduate

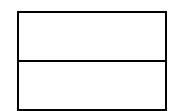

A4. I am from

UiTM

UMP

UTP

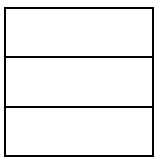

Others:

\section{A5. Faculty}

Faculty of Business and Management

Faculty of Information and Technology

Faculty of Engineering

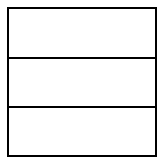

Others:

A6. My MUET result is:

$\begin{array}{ll}\text { Band } 1 & \square \\ \text { Band } 4 & \end{array}$

Band 2

Band 5
Band 3

Band 6 


Section A-Students' perceptions on the use of Social Networking in
improving English Writing skills.
\begin{tabular}{|l|l|l|l|l|}
\hline $\begin{array}{l}\text { Strongly agree } \\
1\end{array}$ & $\begin{array}{l}\text { Agree } \\
2\end{array}$ & $\begin{array}{l}\text { Neutral } \\
3\end{array}$ & $\begin{array}{l}\text { Disagree } \\
4\end{array}$ & $\begin{array}{l}\text { Strongly } \\
\text { disagree } \\
5\end{array}$ \\
\hline
\end{tabular}

\begin{tabular}{|c|c|c|c|c|c|c|}
\hline No & $\begin{array}{l}\text { Students' perception of the usage SNS in English } \\
\text { Writing }\end{array}$ & & & & & \\
\hline 1. & $\begin{array}{l}\text { I think online chatting helps me to improve my } \\
\text { English writing. }\end{array}$ & 1 & 2 & 3 & 4 & 5 \\
\hline 2. & $\begin{array}{l}\text { I think social networking sites (writing status, } \\
\text { comment) helps me to improve my writing. }\end{array}$ & 1 & 2 & 3 & 4 & 5 \\
\hline 3. & $\begin{array}{l}\text { I think social networking sites language influence } \\
\text { my formal writing positively. }\end{array}$ & 1 & 2 & 3 & 4 & 5 \\
\hline 4. & $\begin{array}{l}\text { I use social networking sites to enhance my } \\
\text { English writing skill. }\end{array}$ & 1 & 2 & 3 & 4 & 5 \\
\hline 5. & $\begin{array}{l}\text { I use social networking sites for learning and } \\
\text { academic purposes. }\end{array}$ & 1 & 2 & 3 & 4 & 5 \\
\hline 6. & $\begin{array}{l}\text { I prefer to write in English when using social } \\
\text { networking sites. }\end{array}$ & 1 & 2 & 3 & 4 & 5 \\
\hline 7. & $\begin{array}{l}\text { I believe that social networking sites is to the } \\
\text { platform to lea }\end{array}$ & 1 & 2 & 3 & 4 & 5 \\
\hline 8. & $\begin{array}{l}\text { I feel comfortable to practice English writing on } \\
\text { social networking sites with my friends. }\end{array}$ & 1 & 2 & 3 & 4 & 5 \\
\hline 9. & $\begin{array}{l}\text { I feel confident to use English on Social } \\
\text { networking sites. }\end{array}$ & 1 & 2 & 3 & 4 & 5 \\
\hline 10. & $\begin{array}{l}\text { I feel good to use English language on Social } \\
\text { networking sites }\end{array}$ & 1 & 2 & 3 & 4 & 5 \\
\hline 11. & $\begin{array}{l}\text { My friends will correct my mistakes on my status } \\
\text { or comment. }\end{array}$ & 1 & 2 & 3 & 4 & 5 \\
\hline 12. & $\begin{array}{l}\text { I am conscious about grammatical structure when } \\
\text { I write on social networking sites. }\end{array}$ & 1 & 2 & 3 & 4 & 5 \\
\hline 13. & $\begin{array}{l}\text { I am conscious about spelling when I write on } \\
\text { social networking sites. (chat, comment and write) }\end{array}$ & 1 & 2 & 3 & 4 & 5 \\
\hline 14. & $\begin{array}{l}\text { I am conscious about punctuation when I write on } \\
\text { Social networking sites (Chat, comment and write } \\
\text { status) }\end{array}$ & 1 & 2 & 3 & 4 & 5 \\
\hline 15. & $\begin{array}{l}\text { Peer comment on the SNS really helped me to } \\
\text { improve my writing in English. }\end{array}$ & 1 & 2 & 3 & 4 & 5 \\
\hline 16. & $\begin{array}{l}\text { I felt comfortable having my peers read my } \\
\text { writing in English through the SNS. }\end{array}$ & 1 & 2 & 3 & 4 & 5 \\
\hline 17. & $\begin{array}{l}\text { I felt comfortable giving feedback to my peers on } \\
\text { their writing in English using SNS. }\end{array}$ & 1 & 2 & 3 & 4 & 5 \\
\hline 18. & $\begin{array}{l}\text { I felt comfortable posting ideas or opinions on } \\
\text { SNS }\end{array}$ & 1 & 2 & 3 & 4 & 5 \\
\hline 19. & $\begin{array}{l}\text { I inculcated a more positive attitude towards } \\
\text { learning English as a second language after using } \\
\text { SNS }\end{array}$ & 1 & 2 & 3 & 4 & 5 \\
\hline 20. & I found it easy to complete my essay using SNS & 1 & 2 & 3 & 4 & 5 \\
\hline 21. & $\begin{array}{l}\text { I prefer writing on SNS than writing in classroom } \\
\text { discussion context because it saves my time. }\end{array}$ & 1 & 2 & 3 & 4 & 5 \\
\hline
\end{tabular}




\section{Section B}

\section{Students' Social Networking Sites preferences to practice English} writing skills.

\begin{tabular}{|l|l|l|l|l|}
\hline $\begin{array}{l}\text { Strongly agree } \\
1\end{array}$ & $\begin{array}{l}\text { Agree } \\
2\end{array}$ & $\begin{array}{l}\text { Neutral } \\
3\end{array}$ & $\begin{array}{l}\text { Disagree } \\
4\end{array}$ & $\begin{array}{l}\text { Strongly } \\
\text { disagree } \\
5\end{array}$ \\
\hline
\end{tabular}

\begin{tabular}{|l|l|l|l|l|l|l|}
\hline No & $\begin{array}{l}\text { Students' preferences of SNS in English writing } \\
\text { skills }\end{array}$ & & & & \\
\hline 1. & $\begin{array}{l}\text { The Social Networking Site I prefer for my } \\
\text { English writing practice is Facebook. }\end{array}$ & 1 & 2 & 3 & 4 & 5 \\
\hline 2. & $\begin{array}{l}\text { The Social Networking Site I prefer for my } \\
\text { English writing practice is Instagram. }\end{array}$ & 1 & 2 & 3 & 4 & 5 \\
\hline 3. & $\begin{array}{l}\text { The Social Networking Site I prefer for my } \\
\text { English writing practice is YouTube }\end{array}$ & 1 & 2 & 3 & 4 & 5 \\
\hline 4. & $\begin{array}{l}\text { The Social Networking Site I prefer for my } \\
\text { English writing practice is Blogspot }\end{array}$ & 1 & 2 & 3 & 4 & 5 \\
\hline 5. & $\begin{array}{l}\text { The Social Networking Site I prefer for my } \\
\text { English writing practice is WhatsApp }\end{array}$ & 1 & 2 & 3 & 4 & 5 \\
\hline 6. & $\begin{array}{l}\text { The Social Networking Site I prefer for my } \\
\text { English writing practice is Telegram. }\end{array}$ & 1 & 2 & 3 & 4 & 5 \\
\hline 7. & $\begin{array}{l}\text { The Social Networking Site I prefer for my } \\
\text { English writing practice is Google }\end{array}$ & 1 & 2 & 3 & 4 & 5 \\
\hline 8. & $\begin{array}{l}\text { The Social Networking Site I prefer for my } \\
\text { English writing practice is Tumblr }\end{array}$ & 1 & 2 & 3 & 4 & 5 \\
\hline 9. & $\begin{array}{l}\text { The Social Networking Site I prefer for my } \\
\text { English writing practice is Twitter }\end{array}$ & 1 & 2 & 3 & 4 & 5 \\
\hline
\end{tabular}

\section{Section C-Open Ended Questions}

Do you think it is good to use Social Networking Sites as a learning and practice English writing skills? if yes, why? If no, why?

Do you think the use of Social Networking Sites could be helpful for your English writing skills? if yes, why? If no, why?

Between the 9 options of Social Networking Site, which one do you prefer the most for English writing practice? Why? 
Table 4.A Research construct and items

\begin{tabular}{ll}
\hline Perception & I feel comfortable to practice English writing on social networking sites \\
on & with my friends. \\
Personal & I feel confident to use English on Social networking sites. \\
feelings & I feel good to use English language on Social networking sites. \\
& I felt comfortable having my peers read my writing in English through \\
& the SNS. \\
& I felt comfortable giving feedback to my peers on their writing in \\
& English using SNS. \\
& I felt comfortable posting ideas or opinions on SNS. \\
& I inculcated a more positive attitude towards learning English as a \\
& second language after using SNS \\
\hline Perception & I think online chatting helps me to improve my English writing. \\
on Academic & I think social networking sites (writing status, comment) helps me to \\
Purposes & improve my writing. \\
& I think social networking sites language influence my formal writing \\
positively. & I use social networking sites to enhance my English writing skill. \\
& I use social networking sites for learning and academic purposes. \\
& I prefer to write in English when using social networking sites. \\
& I believe that social networking sites is the platform to learn. \\
& I found it easy to complete my essay using SNS \\
& I prefer writing on SNS than writing in classroom discussion context \\
because it saves my time.
\end{tabular}

Table 4.A displays the research construct and items following the themes emerge from the theories to answer the research questions. It has been emerging to a perception of personal feelings, perception of academic purposes, and perception of the functionality of SNS. 